\title{
Corporate Social Responsibility on Financial Performance: A Study of the Bangladeshi DSE Listed Private Commercial Banks
}

\author{
Fatima Saki* \\ Department of Accounting and Information Systems, Jatiya Kabi Kazi Nazrul Islam University, Trishal, \\ Mymensingh-2224, Bangladesh
}

\begin{abstract}
The fundamental purpose of the study is to examine the impact of corporate social responsibility (CSR) on the financial performance (FP) of Private Commercial Banks (PCBs) in Bangladesh. The study uses a simple random sampling technique. Ten (10) PCBs are selected as samples for the study from the Dhaka Stock Exchange (DSE) listed companies. Statistical analysis tools such as regression, analysis of variance (ANOVA), and correlation are applied to collected data to examine CSR's impact on selected banks' financial performance. In the study, net profit after tax (NPAT), earnings per share (EPS), net asset value per share (NAVPS), return on assets (ROA), return on equity (ROE), and market value per share (MVPS) are considered as dependent variables and the independent variable, corporate social responsibility (CSR). The findings reveal that the EPS, NAVPS and MVPS of the selected banks are significantly influenced by CSR 56.4, 62.0, and 59.8 percent, respectively. In contrast, CSR has an insignificant relationship with NPAT, ROA, and ROE. The study also indicates a high degree positive and statistically significant correlation between CSR and financial performance (EPS, NAVPS, and MVPS). CSR influences financial performance essentially, so considering social benefits, the banks should perform CSR activities emphasizing educational, environmental, and health issues.
\end{abstract}

Keywords: CSR, Financial Performance, Dhaka Stock Exchange, Private Commercial Banks, Bangladesh

JEL Classification: M14, G21, G320

Paper Type: Research

*Corresponding author: E-mail: sakifatima26@gmail.com 


\section{INTRODUCTION}

Corporate social responsibility (CSR) is the internationally regarded concept for responsible corporate behaviour. CSR indicates a company's moral and ethical foundations regarding their employees, their competitors, the environment, the economy, and other areas of life that its business affects. Corporate social responsibility is an idea whereby companies voluntarily incorporate social and environmental concerns in their business operations and their interaction with stakeholders (Kapur, 2020). CSR includes four dimensions: economic, legal, ethical, and discretionary that the society has of the organizations at a specific point in time (Carroll, 1979 cited by Silveira and Petrini, 2018).

CSR describes a company's promise to be liable to its stakeholders- customers and investors and employees, suppliers, communities, regulators, special interest groups, and society. It is the deliberate inclusion of public interest into corporate decision-making and the honouring of a triple bottom line: people, planet, profit (Fontaine, 2013). Corporate social responsibility activities constitute an essential part of doing banking business ethically and with the public interest.

The history of Bangladesh's banking sector has a long association in welfare activities like donations to various charitable organizations, helping poor people, and providing a scholarship to the students, urban beautification, patronizing art, culture, etc. The latest trends of these involvements indicate that banks are progressively organizing these involvements in a more prepared format, in line with the Bangladesh Bank Guidelines in Department of Off-site Supervision circular number 1 of 2008 and Bangladesh Securities Exchange Commission (BSEC) Guidelines 2018.

The proper implementation of the CSR concept can bring along a variety of competitive advantage and sustainable competitive advantage, such as enhanced access to capital and markets, increased sales and profits, operational cost savings, improved productivity and quality, efficient human resource management, improved brand image and reputation, enhanced customer loyalty and equity, proper decision making and risk management processes, among others. (Dhaliwal, Radhakrishnan, Tsang \& Yang, 2012). In contrast, the companies which do not produce CSR reports can be confronted with problems like bad reputation about the company to the extent of damage of the financial performance.

The study on CSR has two broad perspectives; firstly, a normative approach examining CSR's fundamental principles and why firms should implement particular policies. Secondly, an empirical approach seeks to explain the effect of CSR on the companies' financial performance. The present study concentrates effect of CSR on the financial performance of banking companies in Bangladesh. Over the last two decades, various researchers researched different CSR topics. They reported positive, negative, mixed, and neutral impact of CSR performances. However, the present study contributes to the impact of CSR activities on the banking sector's financial performance, specifically the private commercial banks (PCB) in Bangladesh.

\subsection{LITERATURE REVIEW}

Some relevant literature and international perspectives are reviewed below to identify the research gap and formulate a research design. CSR has become one of the dominant business themes over the last few years (Goss \& Roberts, 2010). CSR contributes to a bank's competitiveness through different approaches. From a relational perspective, a 
bank's legitimacy is rooted in its financial performance and its good reputation among stakeholders.

Reputation can be considered the missing link between CSR engagement and social and economic legitimacy (Gangi, Mustilli, Varrone \& Daniele, 2018). CSR increases both the long-term profitability and growth of the company and increases the goodwill of the enterprise. The maximum international companies observation about CSR as a costly hindrance, while a few have managed to use proper CSR methods, logics as a strategic tactic to obtain public appreciation for their presence in the international markets.

Despite these advantages, the companies sustain a competitive advantage by using their social contributions (Akter, Siddik, \& Mondal, 2018). Fasanya and Onakoya (2013) examined CSR's impact on Nigeria's financial performance based on both primary and secondary data. They employed both descriptive and explanatory objectives. The chisquare technique and content analysis were used to test the significant relationship among the frequencies. The study found that suitable and efficient CSR goes a lengthy way in increasing Nigeria's financial performance. Uadiale and Fagbemi (2012) also assessed the impact of CSR activities on financial performance measured with return on equity $(R O E)$ and returned on assets (ROA) based on the sample of forty audited financial statements of prominent companies in Nigeria and showing the results of CSR has a significant positive relationship with the financial performance measures. The findings highlight the accumulating body of experiential support for the positive impact of CSR on financial performance. Choi, Kwak, and Choe (2010) and Lin, Yang, and Liou (2009) investigated CSR and corporate financial performance and found a positive and significant relationship between corporate financial performance and CSR.

Williams and Siegel (2000) demonstrated a correlation or misspecification between corporate social responsibility and financial performance. They reported a positive, negative, and neutral impact of CSR on financial performance. Akter, Siddik, and Mondal (2018) defined the financial performance of all the banks' financial positions over some particular period and how efficiently a bank produces its resources and improves income. Khan and Tariq (2017) used numerous variables like return on asset (ROA), return on equity (ROE), and earnings per share (EPS) for evaluating the wealth of banks. Choi, Kwak, and Choe (2010) identified the variables such as ROE, ROA, and Tobin's Q for measuring financial performance. Akter, Siddik, and Mondal (2018) considered independent variables in CSR as education, health, humanitarian and disaster relief, environmental and cultural welfare. The dependent variables are performance measurement tools such as ROA, ROE, and EPS of a bank.

Balabanis, Phillips, and Lyall (1998) examined the relationship between CSR and economic performance (return on capital employed, return on equity, gross profit to sales ratios, systematic risk, and excess market valuation) in the top British companies. The study results helped that (past, concurrent and consequent) economic performance is associated with CSR performance and disclosure. Their relationships were weak and lacked an overall consistency.

Mackey, Mackey, and Barney (2007) developed the study on corporate social responsibility and firm performance regarding investor preferences and corporate strategies and suggested that few investors may have interested in wealth maximization in making their investment decisions. Suppose the demand for socially responsible investment opportunities formulated by the investors is better than the supply of these 
investment opportunities. In that case, such investments can raise economic value for a firm.

Waddock and Graves (1997) used a greatly-improved data on corporate social performance (CSP). They reported the results of a demanding study of the empirical linkages between financial and social performance. After observing the study, the CSP was positively associated with previous financial performance and supported the theory of slack resource availability. CSP was positively related. Ahmed, Islam, and Hasan (2012) conducted a study to examine the nature of the relationship between CSR and CFP in Bangladesh's banking sector. He revealed that the average ROA ratio of the banks having high CSP was higher than that of the banks with low CSP. However, this might not be examined statistically.

Arshad, Othman, and Othman (2012) examined the effect of Islamic CSR disclosure on corporate reputation and firm performance. The study results provided evidence that CSR activities communicated in corporate annual reports are significantly and positively related to corporate reputation and firm performance. Azim, Ezaz, and Brian (2011) conducted a CSR study in Bangladesh's financial sector. The study mentioned that CSR is not the only ethical dilemma that financial institutions face in an atmosphere of corrupted corporate practice. Lin, Yang, and Liou (2009) suggested in their study that CSR activities can also have a strong economic rationale in certain conditions of earning profit and serving society.

This empirical study adopts multiple financial indicators to measure the causal relationship between CSR expenditure and bank performance. Thus, the study considers some financial performance as measuring indicators used in the diverse reviewed literature. These financial performance measuring indicators are- NPAT, EPS, NAVPS, ROA, ROE, and MVPS. Though there are several works on corporate social responsibility in the aspects of the environment, society, and financial performance in national and international perspectives, this is another initiative of measuring the impact of CSR activities on financial performance in developing countries like Bangladesh. Hence the study tries to determine CSR's effect on financial performance based on DSE listed private commercial banks in Bangladesh.

\subsection{OBJECTIVES OF THE STUDY}

The study's essential purpose is to investigate CSR's impact on the financial performance (FP) of private commercial banks in Bangladesh. To achieve the critical objective following specific objectives are set out:

a) To identify the significant areas where PCBs are performing CSR activities;

b) To analyze the contribution of CSR activities on the financial performance of PCBs in Bangladesh.

\subsection{METHODOLOGY OF THE STUDY}

The ten private commercial banks listed in DSE are considered the study population through simple random sampling. The sample banks are (i) Dutch Bangla Bank Limited (DBBL), (ii) BRAC Bank Limited, (iii) City Bank Limited (CBL), (iv) Eastern Bank Limited (EBL), (v) NCC Bank Limited (NCCBL), (vi) One Bank Limited (OBL), (vii) Pubali Bank Limited (PBL), (viii) Southeast Bank Limited (SEBL), (ix) Uttara Bank Limited (UBL) and (x) Al-Arafahlslami Bank Limited (AAIBL). The study's data are collected from 2013 to 2018 from the published annual report of the selected PCBs, Bangladesh Bank, 
Bangladesh Securities Exchange Commission (BSEC), published articles, and journals. The statistical tools and techniques like regression, ANOVA, and correlation analysis analyze the collected data with Statistical Package for Social Sciences (SPSS) version 20 software.

\subsection{The variables of the study}

The variables for the study are listed and defined as follows:

$\begin{array}{ll}\begin{array}{ll}\text { Variables (Dependent) } \\ \text { Net Profit After Tax }\end{array} & \begin{array}{l}\text { Acronym } \\ \text { NPAT }\end{array} \\ \text { Earnings per Share } & \text { EPS } \\ \text { Net Asset Value per Share } & \text { NAVPS } \\ \text { Return on Asset } & \text { ROA } \\ \text { Return on Equity } & \text { ROE } \\ \text { Market Value per Share } & \text { MVPS } \\ \begin{array}{l}\text { Corporate Social } \\ \text { Responsibility Expenditure }\end{array} & \text { CSR }\end{array}$

\section{Clarification}

Earnings before interest and tax multiplied by one minus tax rate.

Net income minus preferred dividend divided by weighted average common shares of the company. Net asset value divided by shares outstanding of the company.

Net income is divided by the total asset of the company.

Net income is divided by shareholders' equity of the company.

The price at which the share of the company stock can be acquired.

The amount of PCB expenditure is spent on CSR activities such as education, health \& safety, human rights, child labour, environmental and climate issues, etc.

\subsection{Research Hypotheses}

In order to measure the impact of CSR on the financial performance of PCBs of Bangladesh, the following hypotheses are developed:

1. $\mathrm{H}_{0}$ : There is no significant impact of CSR on NPAT of private commercial banks. $\mathrm{H}_{1}$ : There is a significant impact of CSR on the NPAT of private commercial banks.

2. $\mathrm{H}_{0}$ : There is no significant impact of CSR on the EPS of private commercial banks. $\mathrm{H}_{1}$ : There is a significant impact of CSR on the EPS of private commercial banks.

3. $\mathrm{H}_{0}$ : There is no significant impact of CSR on the NAPVS of private commercial banks. $\mathrm{H}_{1}$ : There is a significant impact of CSR on NAVPS of private commercial banks.

4. $\mathrm{H}_{0}$ : There is no significant impact of CSR on ROA of private commercial banks $\mathrm{H}_{1}$ : There is a significant impact of CSR on the ROA of private commercial banks.

5. $\mathrm{H}_{0}$ : There is no significant impact of CSR on ROE of private commercial banks. $\mathrm{H}_{1}$ : There is a significant impact of CSR on the ROE of private commercial banks.

6. $\mathrm{H}_{0}$ : There is no significant impact of CSR on MVPS of private commercial banks. $\mathrm{H}_{1}$ : There is a significant impact of CSR on MVPS of private commercial banks. 


\subsection{Regression Model}

To analyze the data and test the hypotheses, the following simple linear regression model is developed:

$Y_{i}=\beta_{0}+\beta_{1} X_{i}+\varepsilon_{i}$

Where:

$Y_{i}$ is the dependent variable,

$\beta_{0}$ is the constant term,

$\beta_{1}$ is the coefficient of the study's independent variables.

$X_{i}$ represents independent variable and

$\varepsilon_{\mathrm{i}}$ the standard error term.

The model represents banks' financial performance as the dependent variable, and CSR is considered an independent variable. The specific regression models are as follows:

$$
\begin{aligned}
& \mathrm{NPAT}_{\mathrm{t}}=\beta_{0}+\beta_{1}\left(\mathrm{CSR}_{\mathrm{t}}\right)+\varepsilon_{\mathrm{t}} \\
& \mathrm{EPSS}_{\mathrm{t}}=\beta_{0}+\beta_{1}\left(\mathrm{CSR}_{\mathrm{t}}\right)+\varepsilon_{\mathrm{t}} \\
& \mathrm{NAVPS}_{\mathrm{t}}=\beta_{0}+\beta_{1}\left(\mathrm{CSR}_{\mathrm{t}}\right)+\varepsilon_{\mathrm{t}} \\
& \text { ROA }_{\mathrm{t}}=\beta_{0}+\beta_{1}\left(\mathrm{CSR}_{\mathrm{t}}+\varepsilon_{\mathrm{t}}\right. \\
& \text { ROE }_{\mathrm{t}}=\beta_{0}+\beta_{1}\left(\mathrm{CSR}_{\mathrm{t}}\right)+\varepsilon_{\mathrm{t}} \\
& \text { MVPS }_{t}=\beta_{0}+\beta_{1}\left(\mathrm{CSR}_{\mathrm{t}}\right)+\varepsilon_{\mathrm{t}}
\end{aligned}
$$

\subsection{ANALYSIS AND FINDINGS}

Table 1 shows the results of simple linear regression analysis. The result indicates that the coefficient of determination is 0.004 in model 1 , so about 0.4 percent of the NPAT data variation is explained by CSR. In model 2 , the $R^{2}$ value estimated as 0.564 indicates that the independent variable CSR significantly determines 56.4 percent of the EPS variance. The coefficient of determination is 0.620 in model 3 . Therefore about 62.0 percent of the variation in the NAVPS data is significantly explained by CSR. Model 4 indicates that the independent variable CSR determines 7 percent of the ROA variance, which is explained insignificantly by the CSR. Model 5 indicates that the independent variable CSR explained 3.3 percent of the dependent variable ROE variance, which is also insignificant. Finally, model 6 determines the $R^{2}$ value as 0.598 , which indicates that the independent variable CSR is significantly explained by 59.8 percent of the MVPS variance.

Table 1. Regression Results

\begin{tabular}{|l|l|l|l|l|l|l|l|}
\hline Model Summary & \multicolumn{2}{l|}{ ANOVA Results } \\
\hline Model & $\begin{array}{l}\text { Predictors } \\
\text { (Constant) }\end{array}$ & $\begin{array}{l}\text { Dependent } \\
\text { Variable }\end{array}$ & $\begin{array}{l}\mathbf{R} \\
\text { Square }\end{array}$ & $\begin{array}{l}\text { Adjusted R } \\
\text { Square }\end{array}$ & $\begin{array}{l}\text { Std. Error of } \\
\text { the Estimate }\end{array}$ & F & Sig. \\
\hline 1 & CSR & NPAT & .004 & -.013 & 1000.94268 & .228 & .635 \\
\hline 2 & CSR & EPS & .564 & .557 & 2.27547 & 75.091 & .000 \\
\hline 3 & CSR & NAVPS & .620 & .614 & 12.50206 & 94.776 & .000 \\
\hline 4 & CSR & ROA & .007 & -.010 & .37427 & .435 & .512 \\
\hline 5 & CSR & ROE & .033 & .016 & 4.10583 & 1.958 & .167 \\
\hline 6 & CSR & MVPS & .598 & .591 & 21.37679 & 86.265 & .000 \\
\hline
\end{tabular}

Source: Authors' calculation based on data from annual reports of selected PCBs during 2013-2018 
The one-way ANOVA Table 1 indicates that the regression model predicts the dependent variable significantly well, except the models 1,4 , and 5 . In this study, the p-value is compared to an alpha level typically 0.05 . Model 1 shows that the $p$-value is 0.635 , which is above 0.05 . So, null hypothesis- 1 is accepted, and alternative hypothesis- 1 is rejected. Therefore, there is an insignificant statistical impact of CSR on NPAT. Model 2 shows that the p-value is 0.000 , which is below 0.05 . So null hypothesis- 2 is rejected, and alternative hypothesis-2 is accepted. Therefore, there is a statistically significant impact of CSR on EPS.

Model 3 shows that the p-value is 0.000 , which is below 0.05 . So null hypothesis- 3 is rejected, and alternative hypothesis-3 is accepted. Therefore, there is a statistically significant impact of CSR on NAVPS. Model 4 shows that the p-value is 0.512 , which is above 0.05 . So null hypothesis- 4 is accepted, and alternative hypothesis- 4 is rejected. Therefore, there is a statistically insignificant impact of CSR on ROA.

In model 5 , it shows that the p-value is 0.167 , which is above 0.05 . So, null hypothesis- 5 is accepted, and alternative hypothesis- 5 is rejected. Therefore, there is an insignificant statistical impact of CSR on ROE. Model 6 shows that the p-value is 0.000 , which is below 0.05 . So null hypothesis- 6 is rejected, and alternative hypothesis- 6 is accepted. Therefore, there is a statistically significant impact of CSR on MVPS.

Table 2. Coefficients of the Estimated Regression Model

\begin{tabular}{|c|c|c|c|c|c|}
\hline \multirow[t]{2}{*}{ Model } & \multicolumn{2}{|c|}{ Unstandardized Coefficients } & \multirow{2}{*}{$\begin{array}{l}\text { Standardized } \\
\text { Coefficients } \\
\text { Beta }\end{array}$} & \multirow[t]{2}{*}{$T$} & \multirow[t]{2}{*}{ Sig. } \\
\hline & B & Std. Error & & & \\
\hline $\begin{array}{l}\text { 1. (Constant) } \\
\text { CSR }\end{array}$ & $\begin{array}{l}2373.537 \\
.201\end{array}$ & $\begin{array}{l}146.835 \\
.421\end{array}$ & .063 & $\begin{array}{l}16.165 \\
.477\end{array}$ & $\begin{array}{l}.000 \\
.635\end{array}$ \\
\hline \multicolumn{6}{|c|}{ a. Dependent Variable: NPAT } \\
\hline $\begin{array}{l}\text { 2. (Constant) } \\
\text { CSR }\end{array}$ & \begin{tabular}{|l|}
2.721 \\
.008 \\
\end{tabular} & \begin{tabular}{|l|}
.334 \\
.001
\end{tabular} & .751 & $\begin{array}{l}8.151 \\
8.666 \\
\end{array}$ & $\begin{array}{l}.000 \\
.000\end{array}$ \\
\hline \multicolumn{6}{|c|}{ a. Dependent Variable: EPS } \\
\hline $\begin{array}{l}\text { 3. (Constant) } \\
\text { CSR }\end{array}$ & \begin{tabular}{|l|}
22.744 \\
.051
\end{tabular} & \begin{tabular}{|l|}
1.834 \\
.005 \\
\end{tabular} & .788 & \begin{tabular}{|l|}
12.401 \\
9.735 \\
\end{tabular} & $\begin{array}{l}.000 \\
.000\end{array}$ \\
\hline \multicolumn{6}{|c|}{ a. Dependent Variable: NAVPS } \\
\hline $\begin{array}{l}\text { 4. (Constant) } \\
\text { CSR }\end{array}$ & \begin{tabular}{|l|}
1.157 \\
.000 \\
\end{tabular} & $\begin{array}{l}.055 \\
.000\end{array}$ & -.086 & \begin{tabular}{|l|}
21.068 \\
-.660 \\
\end{tabular} & $\begin{array}{l}.000 \\
.512\end{array}$ \\
\hline \multicolumn{6}{|c|}{ a. Dependent Variable: ROA } \\
\hline $\begin{array}{l}\text { 5. (Constant) } \\
\text { CSR }\end{array}$ & \begin{tabular}{|l|}
12.914 \\
.002
\end{tabular} & $\begin{array}{l}.602 \\
.002\end{array}$ & .181 & \begin{tabular}{|l|}
21.441 \\
1.399 \\
\end{tabular} & $\begin{array}{l}.000 \\
.167\end{array}$ \\
\hline \multicolumn{6}{|c|}{ a. Dependent Variable: ROE } \\
\hline $\begin{array}{l}\text { 6. (Constant) } \\
\text { CSR }\end{array}$ & \begin{tabular}{|l}
22.860 \\
.084
\end{tabular} & $\begin{array}{l}3.136 \\
.009\end{array}$ & .773 & \begin{tabular}{|l}
7.290 \\
9.288
\end{tabular} & $\begin{array}{l}.000 \\
.000\end{array}$ \\
\hline
\end{tabular}

Source: Authors' calculation based on data from annual reports of selected PCBs during 2013-2018

The coefficients table provides the necessary information to predict NPAT, EPS, NAVPS, ROA, ROE, and MVPS regarding CSR. It determines whether CSR contributes statistically significantly to the model. The study found that CSR significantly influences EPS, NAVPS, and MVPS because of high beta values. In contrast, CSR insignificantly influences NPAT, ROA, and ROE because of low beta values. It is found that CSR has a direct positive insignificant impact on NPAT and ROE. In contrast, CSR has a negative impact on ROA. It is also revealed that CSR has a direct positive significant impact on EPS, NAVPS, and MVPS. 
Table 3: Estimated Results of Correlation Analysis

Correlations Matrix

\begin{tabular}{|c|c|c|c|c|c|c|c|c|}
\hline & & CSR & NPAT & EPS & NAVPS & ROA & $\mathrm{ROE}$ & MVPS \\
\hline \multirow[t]{2}{*}{$\overline{C S R}$} & $\begin{array}{l}\text { Pearson Correlation } \\
\text { Siq (2-tailed) }\end{array}$ & 1 & & & & & & \\
\hline & $\mathrm{N}$ & 60 & & & & & & \\
\hline \multirow[t]{2}{*}{ NPAT } & $\begin{array}{l}\text { Pearson Correlation } \\
\text { Sig. (2-tailed) }\end{array}$ & $\begin{array}{l}.063 \\
635\end{array}$ & 1 & & & & & \\
\hline & $\mathrm{N} \cdot(2-\cos (\mathrm{s})$ & 60 & 60 & & & & & \\
\hline \multirow[t]{2}{*}{ EPS } & $\begin{array}{l}\text { Pearson Correlation } \\
\text { Sia (2-tailed) }\end{array}$ & $\begin{array}{l}.751^{* *} \\
000\end{array}$ & $\begin{array}{l}.352^{* *} \\
006\end{array}$ & 1 & & & & \\
\hline & $\mathrm{N}$ & 60 & 60 & 60 & & & & \\
\hline \multirow[t]{2}{*}{ NAVPS } & $\begin{array}{l}\text { Pearson Correlation } \\
\text { Sig. (2-tailed) }\end{array}$ & $\begin{array}{l}.788^{* *} \\
.000\end{array}$ & $\begin{array}{l}.145 \\
.268\end{array}$ & $\begin{array}{l}.929^{* *} \\
.000\end{array}$ & 1 & & & \\
\hline & $\mathrm{N}$ & 60 & 60 & 60 & 60 & & & \\
\hline \multirow[t]{2}{*}{ ROA } & $\begin{array}{l}\text { Pearson Correlation } \\
\text { Sig. (2-tailed) }\end{array}$ & $\begin{array}{l}-.086 \\
.512\end{array}$ & $\begin{array}{l}.648^{* *} \\
.000\end{array}$ & $\begin{array}{l}.189 \\
.148\end{array}$ & $\begin{array}{l}-.050 \\
.703\end{array}$ & 1 & & \\
\hline & $\mathrm{N}$ & 60 & 60 & 60 & 60 & 60 & & \\
\hline \multirow[t]{3}{*}{ ROE } & Pearson Correlation & 181 & $.640^{* *}$ & $.436^{* *}$ & .168 & $.741^{* *}$ & 1 & \\
\hline & Sig. (2-tailed) & .167 & .000 & .000 & .199 & .000 & & \\
\hline & $\mathrm{N}$ & 60 & 60 & 60 & 60 & 60 & 60 & \\
\hline \multirow[t]{3}{*}{ MVPS } & Pearson Correlation & $.773^{* *}$ & $.358^{* *}$ & $.871^{* *}$ & $.897^{* *}$ & .118 & $.345^{* *}$ & 1 \\
\hline & Sig. (2-tailed) & .000 & .005 & .000 & .000 & .368 & .007 & \\
\hline & $\mathrm{N}$ & 60 & 60 & 60 & 60 & 60 & 60 & 60 \\
\hline
\end{tabular}

** correlation is significant at the 0.01 level (2-tailed)

Source: Authors' calculation based on data from annual reports of selected PCBs during 2013-2018

Table 3 shows a high degree positive correlation between CSR and EPS, NAVPS and MVPS, EPS and NAVPS, MVPS. The study also reveals a high degree of a positive correlation between NPAT and MVPS, ROA, and ROE. A moderate degree of positive correlation is found between NPAT and ROA, ROE. The study also finds a low degree positive correlation between NPAT and EPS, MVPS, EPS, and ROE lastly ROE and MVPS. Moreover, this study explores the negative correlation between CSR and ROA, NAVPS, and ROA. Lastly, the study also reveals the very weak positive correlation among the variables such as: with CSR and NPAT, ROE, between NPAT and NAVPS, EPS and ROA, NAVPS and ROE, and at last ROA and MVPS.

\subsection{CONCLUSION}

The study's fundamental purpose is to investigate the effect of corporate social responsibility (CSR) on DSE-listed private commercial banks' financial performance in Bangladesh. This study used a sample of 10 companies listed in DSE from 2013 to 2018. CSR activities remarkably influence the EPS, NAVPS and MVPS of the sample banks. The calculated percentage of impact is 56.4, 62.0, and 59.8, respectively. However, the other selected variables (NPAT, ROA, and ROE) are not remarkably influenced. ANOVA determines that null hypothesis- 1 , hypothesis- 4 , and hypothesis- 5 are accepted, and their alternative hypotheses are rejected.

The null hypothesis-2, null hypothesis-3, and null hypothesis- 6 are rejected, and their alternative hypotheses are accepted. The estimated coefficient value shows that CSR significantly positively influences EPS, NAVPS, and MVPS because of the high beta value. In contrast, CSR has insignificantly positively influenced NPAT and ROE because of low beta value, and CSR negatively influences ROA. The correlation analysis shows a statistically significant positive correlation between CSR and EPS, NAVPS and MVPS; NPAT and EPS, ROA, ROE and MVPS; EPS and NAVPS, ROE MVPS; NAVPS with 
MVPS; ROA with ROE; and ROE with MVPS. As CSR has a significant positive impact on performance, considering Bangladesh's perspective, banks should contribute more to CSR activities emphasizing environment, education, health, human rights, child labour, climate issue, etc.

\section{REFERENCES}

Ahmed, S. U., Islam, M. Z., \& Hasan. K. (2012). Corporate social responsibility and financial performance linkage: Evidence from Bangladesh's banking sector. Journal of Organizational Management, 1(1), 1421.

Akter, N., Siddik, A. B., \& Mondal, M. S. A. (2018). Corporate social responsibility disclosure practices and banks financial performance: A study on listed private commercial banks in Bangladesh. Journal of Business and Technology (Dhaka), Northern University, Bangladesh, 8(1), 1-19.

Arshad, R., Othman, S., \& Othman, R. (2012). Islamic corporate social responsibility, corporate reputation, and performance. Journal of World Academy of Science, Engineering and Technology, 64, 1070-1074.

Azim, M., Ezaz, A., \& Brian, D. (2011). Corporate social disclosure in Bangladesh: A study of the financial sector. International Review of Business Research Papers, 7(2), 37-55.

Balabanis, G., Philips, H., \& Lyall, J. (1998). Corporate social responsibility and economic performance in the top British companies: Are they related? European Business Review, 98(1), 25-44.

Berenson, M. L., D. M. Levine \& Krehbiel, T. C. (2004). Basic Business Statistics, 9th ed., Upper Saddle River, New Jersey: Pearson/Prentice Hall.

Choi, J. S., Kwak, Y.M., \& Choe, C. (2010). Corporate social responsibility and corporate financial performance: Evidence from Korea. Australian Journal of Management, 35(3), 291-312.

Dhaliwal, D.S., Radhakrishnan, S., Tsang, A., \& Yang, J. G. (2012). Nonfinancial disclosure and analyst forecast accuracy: International evidence on corporate social responsibility disclosure. The Accounting Review, 87(3), 723-759.

Fasanya, I. O., \& Onakoya, A. B. O. (2013). Does corporate social responsibility improve the financial performance of Nigerian firms? Empirical evidence from triangulation analysis. Acta Universitatis Danubius, 9(3), 22-36.

Fleiss, J. L., Levin, B., \& Paik, M. C. (2003). Statistical Methods for Rates and Proportions. Third Edition, John Wiley \& Sons, New York.

Fontaine, M. (2013). Corporate social responsibility and sustainability: The new bottom line? International Journal of Business and Social Science, 4(4), 110-119.

Gangi, F., Mustilli, M., Varrone, N., \& Daniele, L. M. (2018). Corporate social responsibility and banks' financial performance. International Business Research, 11(10), 42-58.

Goss, A., \& Roberts, G. S. (2010). The impact of corporate social responsibility on the cost of bank loans. Journal of Banking \& Finance, 35(2011). 1794-1810. https://doi.org/10.1016/j.jbankfin.2010.12.002

Holme, L., \& Watts R. (2007). "Making good business sense" The World business council for sustainable development. Available at: http://www.mallenbaker.net/csr/ definition.php (12-2-2010)

Igwenagu, C. (2016). Fundamentals of research methodology and data collection. LAP Lambert Academic Publishing, 1-48.

Kapur, R. (2020). Corporate social responsibility. Department of Adult, Continuing Education \& Extension, University of Delhi.

Khan, B., \& Tariq, R. (2017). Corporate social responsibility impact on the financial performance of Islamic and conventional banks: Evidence from Asian countries. Research Journal of Finance and Accounting, $8(7), 20-28$.

Kothari, C. R. (1990). Research methodology-methods \& techniques. $2^{\text {nd }}$ ed., Vishwa Prakashan, New Delhi.

Lesikar, Raymond V., \& John D. Pettit, Jr. (1998). Report writing for business: Tenth Edition. Delhi: McGrawHill.

Lin, C. H., Yang, H. L., \& Liou, D. Y. (2009). The impact of corporate social responsibility on financial performance: Evidence from business in Taiwan. Technology in Society, 31, 56-63.

Mackey, A., Mackey, T. B., \& Barney, J. B. (2007). Corporate social responsibility and firm performance: Investor preferences and corporate strategies. Academy of Management Review, 32(3), 817-835.

Silveira, L. M. \& Petrini, M. (2018). Sustainable development and corporate social responsibility: A bibliometric analysis of international scientific production. Journal of Gest. Prod., São Carlos, 25(1), p. 56-67.

Uadiale, O. M., \& Fagbemi, T. O. (2012). Corporate social responsibility and financial performance in developing economies: The Nigerian Experience. Journal of Economics and Sustainable Development, 3(4), 44-55.

Waddock, S. A., \& Graves, S. B. (1997). The corporate social performance-Financial performance link. Strategic Management Journal, 18(4), 303-319. 
Saki, F.

Williams, A. M., \& Siegel, D. (2000). Corporate social responsibility and financial performance: Correlation or misspecification? Strategic Management Journal, 21(5), 603-609. 